\title{
PALAVRA DO EDITOR
}

Este número da Revista do Gel, do ano de 2019, que é o primeiro gestado no âmbito do Volume 16 da Revista, teve de enfrentar as condições adversas que as mudanças na cultura e na lógica de produção acadêmica impuseram à nossa realidade, em especial à das Humanidades.

A corrida pela publicação de artigos em revistas especializadas, por pesquisadores consolidados, pós-graduandos e graduandos, pressionou a engrenagem editorial. Para além da divulgação do trabalho de pesquisa, o artigo científico assumiu novos estatutos, inserido em novas práticas acadêmicas: creditação, pré-requisito, pontuação, critério para captação de recursos.

Mais artigos circulando, maior o número de pareceristas demandados. Pareceristas estes que são pesquisadores e professores que enfrentam, já há alguns anos, uma sobrecarga nos âmbitos do ensino, da pesquisa, da extensão e da gestão, que nasce da precarização das condições de trabalho e da não reposição dos quadros.

Em um cenário como esse, foi necessária muita paciência e resignação. Por essa razão, agradecemos, já de início, a confiança de todas e todos que nos enviaram suas contribuições e, sobretudo, agradecemos o trabalho desses pareceristas que, ainda que acumulem muitas funções, dedicaram-se a ler, comentar e debater os textos que recebemos. Sem todo esse processo, que exige idas e vindas, nada seria possível. É também muito importante lembrar do apoio da Diretoria do GEL, que nos deu as condições necessárias (logísticas, materiais) para a realização de mais este número.

Quanto aos trabalhos que aqui apresentamos, são artigos que permitem um olhar panorâmico sobre a pesquisa que se faz nas áreas de Linguística e Letras, na medida em que tratam de problemas relativos à Semântica lexical, Linguística histórica, Gramaticalização em Língua Brasileira de Sinais, Terminologia e Estudos do Discurso e do texto Literário.

O número se inicia com o trabalho de Thaís Bechir, intitulado "A analise da relevância propriedade semântica 'reciprocidade' nos verbos intransitivos do português brasileiro", que tem por objetivo analisar os verbos recíprocos intransitivos e verificar se eles podem ser agrupados em uma só classe no português brasileiro, discutindo assim o estatuto da propriedade semântica reciprocidade.

O segundo artigo, "O apagamento das consoantes róticas finais: um estudo comparativo entre o português arcaico e o português brasileiro", de Débora Aparecida dos Reis Justo Barreto e Gladis Massini-Cagliari, mostra o processo de apagamento da 
consoante rótica final no português brasileiro de hoje (PB) e no português arcaico (PA), a partir do estudo das Cantigas de Santa Maria, indicando que, ao contrário do que ocorre hoje em PB, o -r final não sofria apagamento em PA.

Angélica Rodrigues e Joyce Cristina Souza, no trabalho intitulado "Gramaticalização do sinal 'motivo' na língua brasileira de sinais: uma análise baseada no uso", trazem uma importante contribuição para os estudos sobre gramaticalização em línguas sinalizadas, de forma geral. A análise inédita das pesquisadoras sobre os usos do sinal motivo na Língua Brasileira de Sinais, glosado frequentemente como "por isso" ou "por causa", oferece evidências do seu uso polissêmico e multifuncional, na medida em que ao ser usado como nome, advérbio e conjunção, acaba por representar diferentes estágios de gramaticalização.

Em "Internacionalização e linguagem institucional: estudo da equivalência do termo 'faculdade' para o Inglês Internacional', Regiani Aparecida Santos Zacarias e Dener Martins de Oliveira buscam averiguar a relação de divergência na direção portuguêsinglês do termo "faculdade", apresentando um estudo que possa servir como referência na escolha de um equivalente em inglês para esse termo "faculdade", a partir do estudo em dicionários monolíngues de língua portuguesa e bilíngue português-inglês. O trabalho se inscreve num objetivo maior, que tem como cenário a internacionalização das Instituições de Ensino Superior (IES), buscando assim promover, nesse cenário, uma maior adequação do uso do termo "faculdade", facilitando ao consulente estrangeiro a compreensão do perfil organizacional das IES brasileiras.

No trabalho de Alana Destri e Anselmo Lima, intitulado "Nostalgia em editoriais da Revista Ferrovia: um estudo discursivo", busca-se compreender de que modo o sentimento de nostalgia, considerado pelos autores como uma forma de expressão da saudade, se organiza de maneira discursiva. Com base na teoria dos gêneros discursivos de Bakhtin, e tendo como córpus 87 editoriais da Revista Ferrovia, Destri e Lima descrevem a forma relativamente estável da manifestação da nostalgia no discurso presente nos editoriais.

Jean Cristtus Portela, em "Semiótica e ideologia", apresenta uma breve história da relação da semiótica discursiva com o conceito de ideologia, refletindo, especialmente, sobre o modo como se deu, no Brasil, com autores pioneiros como Edward Lopes, José Luiz Fiorin e Diana Luz Pessoa de Barros, a antecipação de certas preocupações teóricas que, na Europa, veio a desenvolver apenas bem recentemente.

No artigo "Django livre: do cinema para os quadrinhos, uma tradução intersemiótica", Mariana de Souza Coutinho e Renata Mancini trazem um estudo sobre Django Livre (2012), do diretor Quentin Tarantino, adaptado para uma série de sete revistas 
em quadrinhos. As autoras chamam a atenção da direção pouco usual desse processo, que parte do cinema para as histórias em quadrinhos, e apresentam uma análise sobre o ritmo das duas obras (partida e chegada), relacionando as transições de quadros com a montagem da linguagem cinematográfica.

O artigo "Sobre sonetos, discursos e jornais: sátira e galhofa no conto 'Aurora sem dia', de Machado de Assis", de Márcio Miranda Alves, traz um análise da relação entre a sátira do conto e a linguagem satírica do Correio Mercantil, que atacava os adversários por meio do humor. Para Alves, o conto de Machado não é apenas uma representação do universo da imprensa, mas reflete também a linguagem jornalística de uma época.

Por fim, é preciso dizer, mais uma vez, que a continuidade de um trabalho científico como o de uma revista acadêmica, especialmente no Brasil de hoje, só tem sido possível graças ao engajamento de pesquisadores, professores, colegas de toda parte, que nos enviam textos continuamente, nos apoiam e partilham conosco um sonho - ou um modelo de país e de Universidade - que só se poderá realizar como projeto coletivo.

Matheus Nogueira Schwartzmann

Editor da Revista do GEL 